\title{
ABAA CASE STUDY: JOURNEY OF THE VEILED
}

\section{ENTREPRENEUR}

Dr. Shahid Qureshi, Program Director, Centre for Entrepreneurial Development, IBA, University

Road, Karachi-75270. Phone: 111-422-422, Fax: (+92-21) 99261508,

Quresh.shahid@gmail.com*correspondence author

Neha Ekhlaq, Research assistant, Centre for Entrepreneurial Development, IBA

\begin{abstract}
The case describes the entrepreneurial journey of a passionate and dedicated young female entrepreneur, Hareem Zahid. She is a 2016 graduate from Institute of Business Administration (IBA), where she completed her bachelor's degree in BBA Entrepreneurship. Her journey reflects that how she entered into the Entrepreneurship program at IBA, and the sequence of events led her to the frivolous pursuit of starting an online venture of ABAA. The venture came into being in January 2013, and climbed the ladder of success in a span of almost 2 years. ABAA's philosophy is to help the modest women find refined elegance, versatility and style in their modest wardrobe, with no compromise on quality and affordability of price.

This case elaborates the journey embarked upon by Hareem, who set foot in this venture with a spiritual orientation, where rather than pursuing things with a fiercely competitive mindset, she developed a mindset which seeks the pleasure of Almighty Allah (swt), with a belief of cooperation and customer service. The story of ABAA depicts that a high spiritual orientation along with an entrepreneurial mindset led Hareem to do something which creates real value and helps her to live a meaningful life. The case further examines the vision Hareem had of expanding her business and taking it to the next level.

The case is extremely pertinent because of the dearth of literature available on female entrepreneurs in Pakistan. It aims to shed light on the mushroom growth of the women-led online business sphere in Pakistan.
\end{abstract}

\section{Keywords}

Women entrepreneurship, spiritual orientation, opportunity recognition, strategic growth options, entrepreneurial skills, creativity, entrepreneurial marketing, women-centered family business. 
Hareem was reflecting on the entrepreneurial journey she went through since her graduation from Institute of Business Administration (IBA), four years ago. A smile spread across her face, while Hareem recalled the first semester, when she joined the new BBA Entrepreneurship program at IBA, and at that time she didn't even know what "Entrepreneurship" meant. She already had a passionate pursuit of becoming a designer, and IBA facilitated her to learn those tricks of running a business, which helped her to establish the brand "ABAA". All it initially had was some family capital, a team of parents, and Hareem's pure passion.

Over the span of 4 years, establishing a business was not an easy task for Hareem. She started off with an investment of 35,000 PKR and was able to sustain the business with the help of her greatest support, her parents. The Entrepreneurship course at IBA, paved a clear path for Hareem on the major strategic objectives that she required to achieve further growth. To climb the ladder of growth, she could either opt to establish a strong online foothold for now, or she could take one further step ahead for expansion i.e. to open up her own flagship store. She was contemplating on her next move.

\section{Hareem Zahid, the Entrepreneur}

Hareem Zahid was born in an upper middle-class and a conservative family, where doing business for a woman was not even contemplated upon. She spent the early years of her life under the shade of a Madrasah (an Islamic Religious School), where she became a Hafizah (a term used by Muslims for people who have completely memorized the Holy Book). Therefore, she got almost no exposure towards modern schooling. After completing her education at the Madrasah, she got admission in the 7th grade in a nearby school. The students there were judged on how well they scored in chemistry, physics and mathematics, but were never appreciated for their out-of-the-box ideas in various spheres of life. After Hareem passed Matriculation, she had to make a career decision. She followed her friends, and chose Engineering as a future career option.

Hareem liked to live on edges, as instead of proper planning and predictably she wanted to fill her life with creativity and innovation. She used to dream of doing something creative, but never had any concrete path to walk on. Gradually her dream took shape, and she became aware of her innate artistic sense. Since inception Hareem was fond of designing casual, evening wear, and full length gowns. As she started wearing an Abaya, which was back in 10th grade-, she became interested in designing Abaya's, because of their length and grace. Hareem, like many others, did not find any appropriate Abaya to wear. She had always been very conscious of what she wore. She had an eye for cuts, details, fall and flare, and used to spend hours designing her personal lawn dresses. All these things also reflected in the Abayas that she wore when she became a Hijabi. (A women or girl who wears the Islamic head-covering respectfully, called Hijab)

Therefore, Hareem decided to become a designer, but due to cultural reasons her parents did not agree on letting her join a Fashion Designing school. Still, the entrepreneurial passion kept growing inside her. Soon came the time when Hareem had to apply for her bachelor's degree, and her father permitted her to apply for the admission test of only one university that was near her home, Institute of Business Administration (IBA). As Hareem was blessed with an intelligent mind, she applied and luckily got admission in IBA's Bachelors Program (BBA). She was the first one in her family to pursue a bachelor's degree from a prestigious university. She was constantly on the lookout for something meaningful that could channelize her passion. 
One day while walking on the foyer area in the campus, Hareem met Ayesha Akram, a senior at IBA. Ayesha was already running a well-established business of her own by the name of Ash L'amour. She complimented Hareem on an Abaya she was wearing, and gave her an inner motivation to start her own venture. Ayesha guided her about the new BBA Entrepreneurship Program being offered at IBA. With the idea of doing 'something' other than a job, Hareem decided to switch from a normal BBA program to the new BBA Entrepreneurship program. Ayesha's advice became the turning point for Hareem, to take a leap of faith and join the new BBA Entrepreneurship program.

During the course of her journey in this program, Hareem learnt various theories and practical application of Entrepreneurship. The most beneficial was the "Effectuation theory", which gave her a new vision of how a person could start a venture with the help of the slack resources available to her.

\section{Breaking conservative stereotypes}

Hareem was determined and stuck to the idea of the Abaya business irrespective of the fact that starting a business was considered rebellious in her family. Her parents believed that when a young woman had to embark upon such a venture, she had to go beyond the cultural limits. Therefore, Hareem faced much opposition when she presented the idea to her parents.

\section{Hareem explained:}

"There are two different kinds of limits: One is that if you go beyond it, it is not considered disrespectful towards parents, but just a change of mindset. While, the second type of limit is to go beyond and to do something disrespectful. I did broke the first limit, when I convinced my parents that doing an online clothing business for women is not something to look down upon. Thus, I successfully changed their mindset. However, I refrained from going too far on this path which could have caused inconvenience to them. Like, I never opted for too many exhibitions as my father did not want me to put myself in the hassle of travelling too far."

Therefore, Hareem took her parents into confidence and was able to change their perspective, while respecting their limits.

\section{Launching the Enterprise}

As Hareem was contemplating her next move, she met a friend at IBA, who was running a small home-based Abaya venture. Hareem decided to work in partnership with her. But, it had only been a meager 15 days that due to various issues the coordination between them became difficult. Thus, on the advice of Hareem's mother, the two decided to separate. Her partner kept the Facebook page and the brand name. Hareem's confidence was completely shattered, as she saw her dream evaporated. Little did she know what nature had actually planned for her.

\section{Women-Centered Family Entrepreneurship}

After parting ways with her friend, Hareem felt that her ship has been stuck in the middle of an ocean, where there was no way out. She had only one being to turn to, and therefore, she made supplicate to Allah (swt) to lead her to a path on which she could contribute to the welfare of the society, and at the same time it could become a means to please Him (swt). Hareem's mother consoled her, and told her not to lose hope. In the next few days, her mother brought various 
pieces of fabric to design Abaya's for her. Seeing the enthusiasm of her mother, she started to regain her lost strength.

Soon Hareem decided to establish her own brand with the help of her parents, as a 'womencentered family business'. This was the sign of the acceptance of her supplications, and after few days she recreated a Facebook page and started brainstorming for a new name. On January $18^{\text {th }} 2013$, “ABAA" was finally launched. Therefore, Hareem's parents became the two pillars with the help of which she stood up again. Their support became the beacon of light through which she harbored her ship towards the seashore.

Hareem's mother used to help her in designing different styles of Abayas, giving innovative ideas every time, while her father used to help in bringing all the fabric and in picking and delivering the material from the tailor. In this way, Hareem was able to leverage her family network, and instead of setting individual targets her whole family got involved and reinforced each other in the process of upbringing the brand to what it was today now.

Reflecting on the philosophy of ABAA, Hareem narrated:

"ABAA is not just a venture, or a home-based business that is there to make money. $A B A A$ is a story of passion, dedication and unwavering strength of its 'team', to make a difference to the world, translated into a brand, that exists to serve the modest women and those who wish to choose modesty in future."

\section{Industry Profile- the Market for home-based Abayas}

A casual glance at the prevalent situation in the world depicted the technological breakthroughs being made in every realm of our life. This had a massive impact on industries, which led them towards innovative and efficient methods of production. Along these lines, came an unprecedented advancement in the fashion industry which made a pathway leading to Abaya industry.

Throughout the years, it became a need of the hour for women in Middle East to wear Abaya's. Many stores opened and competition burst between rivals. As the Islamic countries, like UAE, were experiencing phenomenal growth in their Abaya Industry, it paved a pathway for the entrepreneurs across the globe too. Soon, a number of home-based Abaya designers sprouted in many Islamic Countries, including Pakistan. (See Exhibit 1)

\section{New Beginnings}

In the early stage, ABAA's customers were limited to Hareem's family and friends at IBA. However, soon through word-of-mouth, her popularity increased. She got immensely popular amongst the Abaya wearing girls at IBA, and in a short span of time, the orders started pouring in. In those days, social media marketing had encroached the lives of larger segments of society. Thus, Hareem grabbed this opportunity and established her presence online, by making a Facebook page for ABAA. (See Exhibit 2)

Hareem took her inspiration mainly from ancient Islamic art. The designs were more or less from her own mind. She directly got involved in the business and handled most of the affairs herself. The workflow process of the venture followed by Hareem was a detailed one (See Exhibit 3).

\section{An In- Born Entrepreneurial Spirit}

Hareem never attended an arts school, thus she never learned things formally. It was only through her innate ability and passion which helped her understand the cuts and designs, how 
different drapes went about, and how different falls came around. However, after applying all those ideas on her Abaya's, she still tried to keep them modest.

\section{Not to have a Resource is a Resource itself}

When Hareem's mind started wandering on the fact that she doesn't have much capital or resources to embark upon this venture, she recalled one of the basic rules from her course: "We are not disadvantageous; GOD has given us resources if we look around". Therefore, Hareem started viewing useless things as important and realized that she herself had a sea of slack resources at home. Thus, rather than dreaming big, Hareem started off by taking smaller steps, and made a home-based studio, i.e. she used one of her rooms as a storage place to keep the fabric, and stitched Abaya's. The women within Hareems residential area used to visit the studio to have a look at the designs. Though they were not the target market, but they became a means of spreading word-of-mouth in the nearby areas.

Hareem displayed parsimonious behavior, by efficiently using the limited resources that were available to her. She borrowed her cousins DSLR camera for the photo shoot. In the initial days she herself was the model, where she utilized her space at home and did the photography, with a self-timer and a self-made stand. Later, her own friends at IBA used to help her in the photo shoots. Thus, Hareem never hired any professional models for advertising her Abaya's. Moreover, she never compromised on the notion of modesty, and always cropped the face of the models in her shoots, which exemplified her religious morals and values.

This was how ABAA's owner made a new world out of the limited resources she carried with her. The limitation of resources became the reason of unleashing her creativity and to take the plunge in this venture.

\section{Building a People's Pipeline}

Hareem was zealous about controlling not just the Quality of the product that she offered, but also on the Quality of the people in the business. Her strategy was premised on her Golden Rule philosophy of "Treat others as you like to be treated and they would reciprocate". The kindness which she displayed in turn provided her ease of single-handedly managing the major operations of her venture, while remaining in the comfort of her home.

\section{Suppliers}

To keep things easy and in her favor, Hareem bought from specific suppliers only, who offered her discounts in turn for her loyalty and other flexibilities when it came to fabric selection.

\section{Tailor}

Hareem hired a master tailor in a nearby area who had 2-3 workers, working under him. She paid him a premium tailoring cost, and in turn he took care of the stitching requirements and helped Hareem to bring the quality at par with what she claimed it to be. Also, he provided free alteration services, and later he also used to pick and drop Abaya's from her home based studio. 


\section{Courier}

ABAA had been using two types of couriers; COD and Non COD. COD was used for cash on delivery parcels, and Non COD was used for people who chose to pay via bank etc. In the pursuit of finding a cost effective way for COD, Hareem looked around and found a newly emerged start-up of a courier service at her own university. Therefore, without putting herself in the hassle of travelling, she just used to hand over the parcels to them within IBA, and in return they used to hand over the cash to her. Thus, this became a bird in hand for Hareem, and due to an affiliation of IBA, the courier service company used to give her discounted rate for the regular parcel deliveries from their portal.

\section{Market Orientation: Entrepreneurial Marketing Strategy Product}

A Ray of hope

The main vision with which Hareem laid the foundation of her venture was to motivate the new comers and to attract the potential Abaya wearers. This started when she was herself in university and could meet such people face to face and talk to them about hijab. People were apprehensive due to multiple reasons to do hijab. Most of them had no family support for it because they considered it as a hindrance towards a good personality, and since many of these people were young and soon to be married, it directly decreased the chances of decent proposals for their daughter according to many parents, because proposers couldn't really see their real beauty. Hareem took this challenge and directed her efforts towards creating a product that would negate the parents' insecurities, and would enhance consumer's personalities when they wear her product.

As Hareem had a sincere intention, she succeeded in that because almost $80 \%$ of the potential hijabi's in IBA bought their first Abaya from her, because it helped their personalities look flexible, stylish, covered, and respected at the same time.

This was reflected in one of the testimonials of ABAA's customer:

"ABAA gave me the confidence to wear an Abaya for the first time in my university, and I was able to step up and to confront the clichéd concepts of my society regarding Hijaab. ABAA is a story of a brand, which transformed numerous lives in our university and brought the women closer to religion." (See Exhibit 4)

Reflecting upon the journey of ABAA, Hareem narrated:

"One of the most amazing things about my venture is that I get a lot of Dua's (supplications) of my customers. As Abaya itself is a religious thing and at least twice a month one person buys it for the sake of Umrah. I feel delighted when deep down I know that my Abaya's are worn by women doing Umrah in Makkah. This gives me an inner peace and satisfaction."

Things speak themselves

Hareem never did drastic marketing of her brand, rather the value and quality which she displayed while wearing her own Abaya's at IBA, itself was enough to convince the customers about the greatness of the product being offered. Hareem believed in delivering high quality fabric to its customers, and employed class and sophistication into its designs. (See Exhibit 5)

\section{Promotion}

\section{Creating an Impact}

Since, four years Hareem only had used the platform of social media to run and grow her venture. It was a very cost effective way through which she uplifted her brand. Facebook worked 
as an online shop for her business, which marketed its collections, connected customers to the brand and helped her to deliver value to them. Hareem never did extra marketing to get new customers; it was only on the basis of word-of-mouth that her brand reached new heights of success. All her "like's" on Facebook were organic, she never went for paid marketing.

Hareem employed diverse marketing tactics on its page to attract and gain attention. Using creative marketing tools to attract customers became the differentiating factor for her brand, which was rarely found in other Abaya brands. Some of the promotional activities included "Abaya Designing Competition" where the customers were motivated to express their desire and creativity in the form of designing Abayas sketches. The best ones, selected on the basis of customer votes, were awarded with prizes while their designs were acknowledged and added to the product line. This activity helped Hareem to recognize the customer needs and she was able to see through the eyes of the customers, for the improvement of the product.

Hareem also participated in an exhibition after it's re-launch in January, and had been a part of some carnivals, and other events, setting up stalls for promotion. It also sponsored different Islamic events, in order to promote the brand to the most apt audience. The exhibition played an important role in terms of promotion as all the new collections introduced was a major hit.

Another factor which gave an edge to Hareem in her promotional activities was that all her photo shoots had an excellent image quality. She focused on the aesthetic sense in its photography of the product, because the images were the most significant way to showcase the product as per the online store setup.

\section{Price}

Initially, to make things easy and within reach for the first time Abaya wearer's, and her university friends Hareem used to give them huge discounts. In later growth stages of the venture, to keep her products affordable to her customers Hareem kept a price that lied in the middle of the market price. She never kept a cheap price for her products, and neither went on a premium side, but aimed to set itself in a range which focused more on affordability.

\section{Financial side of the business}

Hareem devised the pricing strategy in a very thoughtful way. Instead of an expensive product, she offered high quality but at an affordable price, and due to her credibility was able to establish a sustainable venture in a span of few years.

As Hareem stated:

"Whatever the inclination is for a person to do business the financial side will always matter, as a business can't grow without it. But I never increased my profit percentage to a large amount. Instead I kept my products towards an affordable category, and made extra efforts to bring the quality at Par. With that mindset, in a very short time span, I was able to make a good earning." (See Exhibit 6)

\section{Factors at Play}

The number of monthly orders varied due to various external factors at play, ranging from seasons of occasions and festivities to seasons of exams and academic engagements. The orders of the month of Ramadan and Eid, were taken before hand, with the delivery halted in the month of Ramadan. As Hareem believed, that this month should be reserved for ABAA's team to do worship. Irrespective of the fact that she could have generated higher revenue by utilizing Ramadan in sales, she still traded off the short-term profit to get a good return in the afterlife. 


\section{A drift towards an Islamic Entrepreneurial Mindset}

Hareem firmly believed in one of the lessons she learned in her course at IBA, that "Entrepreneurs feel closer to GOD than the rest of us do." In every uncertainty she faced in her venture, displaying her humbleness, Hareem used to feel enshrouded with a Divine strength carrying her along the way. Hareem not only matched the necessary requirement of operating a worldly business but she did it with extra commitment, going beyond the basic rules and on every step complied with the Islamic Values.

She always had an urge to do something for her religion and the society as well. She considered working for the afterlife as or even much more important than working for a successful worldly life and that was exactly what drove her to pursue this business.

\section{Working with a Spiritual Orientation}

Hareem learned that it was not always the materialistic resources that a person needs to embark upon a venture, but values like, humbleness and gratitude are also a resource in itself. Thus, she leveraged on various inner qualities that she possessed, and in turn these qualities became her "resource" to establish this venture.

Service to humanity:

"The yardstick by which God will measure my life isn't dollars but the individual people whose lives I've touched." This was a saying which Hareem read in an article by Clayton Christensen discussed in one of her Entrepreneurship class. The words used to echo in Hareem's mind, and she hold on to them tightly. She started developing a mindset that the ultimate vision of every Entrepreneur should be to become a faithful steward, a person who existed to achieve a bigger purpose in life i.e. to carry the responsibility of serving and positively influencing the lives of the people. Thus, following this principle ABAA became the brand through which Hareem served the struggling women of this day and age.

As Hareem explained:

"I wanted to design a product that would kill the opportunity for people to taunt the choice of wearing an Abaya. I wanted to help and lessen the pain of a Hijaabi woman for being different, to choose to cover up, and to sacrifice the urge to show off in this age of materialism, which itself is a difficult task. My brand is not just a piece of cloth; it's an identity and known choice. This idea of contributing to the welfare of the society itself

\section{Balance:} motivates me to put in more time, effort and quality assurance in my business."

Hareem was a lifestyle Entrepreneur and she was very particular about work-life balance and gave time to her business accordingly. Since her venture was a woman run business, all the activities while were managed with the house hold chores. Hareem ran it with wisdom, pause it when needed, restarted when best. This way she kept a balance between life and work, i.e. the practice of moderation, which too is an essential Islamic concept.

Great customer service:

Hareem repeatedly stressed the importance of customer relationships, and often sacrificed shortterm growth and profits for the sake of building enduring loyalty among her customers. To fix any mistakes and improve customer service, Hareem established friendly gestures by creating a $100 \%$ return and exchange policy, with a full refund. She faced a lot of losses because of this 
strategy, but it also helped her to gain and maintain the consumer confidence and loyalty. Moreover, it encouraged repurchases in the brand and also maintained respect in the consumer's mind for the brand's ethical practices and values.

Hareem stated:

"Great customer service nourishes many qualities in us, including: Great character (akhlaaq), honesty, accountability, closeness to GOD, makes one grateful for all the good and patient for the downturn in business, and one realizes that being good to others brings you good from places one hasn't even imagined."

Perseverance:

Juggling ABAA with IBA studies, and later her married life, was a big challenge for Hareem.

Sometimes she was enshrouded with a feeling that she's standing at the edge of an Abyss, i.e. facing uncertainty all around her. She faced a dark side of Entrepreneurship, where she struggled a lot, and managed her own stress level but still hold on to the rope of perseverance. At every point, she knew deep inside that GOD was looking after her. Thus, she never quitted and rode through those difficult times and managed to inspire and to motivate others.

Faith:

Over these years, Hareem nourished the value of having a complete trust in Divine Power, due to which she was never scared of her competitors.

Hareem reflected:

"The competition is really high, as there are better Abaya brands than ABAA. Still I don't have anything to worry about. I always remain grateful for whatever I have achieved, as I have complete trust in Allah (swt) that no one else can take away my share which He has decreed for me".

\section{Envisioning the Future}

Hareem was reflecting upon the progress of ABAA so far. Her business was running quite successfully. Today the brand is making revenue approximately 190,000 PKR monthly, with a profit margin of almost $34 \%$ of sales with only $1 \%$ of paid marketing over the period of 12 months. While reflecting back on her journey, somewhere in her heart Hareem knew that she would have to make key decisions to achieve the level of growth that she aspired to reach.

In her own words:

"ABAA's aim is to make modesty (haya) easier and more accessible for young females, to make them feel confident and graceful about it and make their families realize that there is empowerment and success (falaah) in being modest."

She contemplated two options for future growth. Firstly, she could opt to focus on establishing a strong online foothold. She was aware that this option did not require a substantial amount of capital investment, but making sales through only one online channel, would have limited potential in terms of additional revenue. Secondly; she could opt to open up her own flagship store. But this requires a huge capital investment. She is contemplating her next step. 


\section{Exhibit 1: The Competitor's Profile}

\section{Dibaaj}

Dibaaj is a popular brand name for stylish, modest clothing for Muslim women, designed by Maha Sajid. With their edgy cuts and flowing fabrics their clothes define true elegance. Even better is how their versatile clothes can be transformed into 3-7 styles by being tied in different ways. They can also be worn as jalabiyas, dresses, gowns and simple wrap-overs.

\section{Alifia}

A start-up by Shumaila Hadi, on a vision to provide customized and easy-wear Abaya's to women which suits the environment of Pakistan.

\section{Hareer- Cover with Elegance}

Designed by Sohaima Samad \& Hamna Abdul Samad, the house of Hareer provides the Muslimah; the modest wear Ready to Wear Abayas, Wraps, Hijabs, Jilbabs.

\section{Hijaab Boutique}

An online based Abaya venture, with a mission of "providing fashionable, modern and elegant Abaya's for the modern Muslimah". 


\section{Exhibit 2: ABAA's Facebook Page Screen Grab}
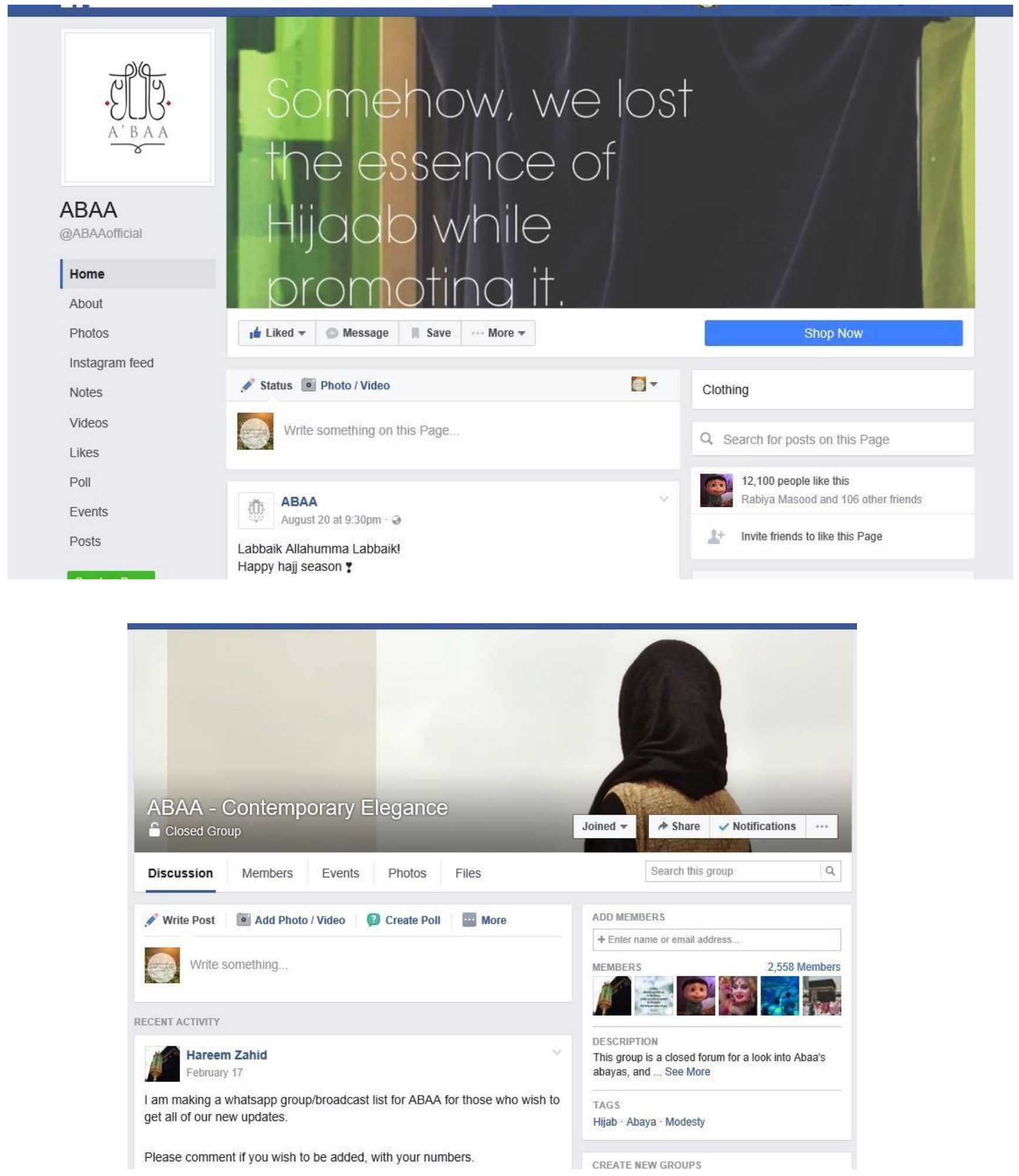


\section{Exhibit 3: ABAA's Process}

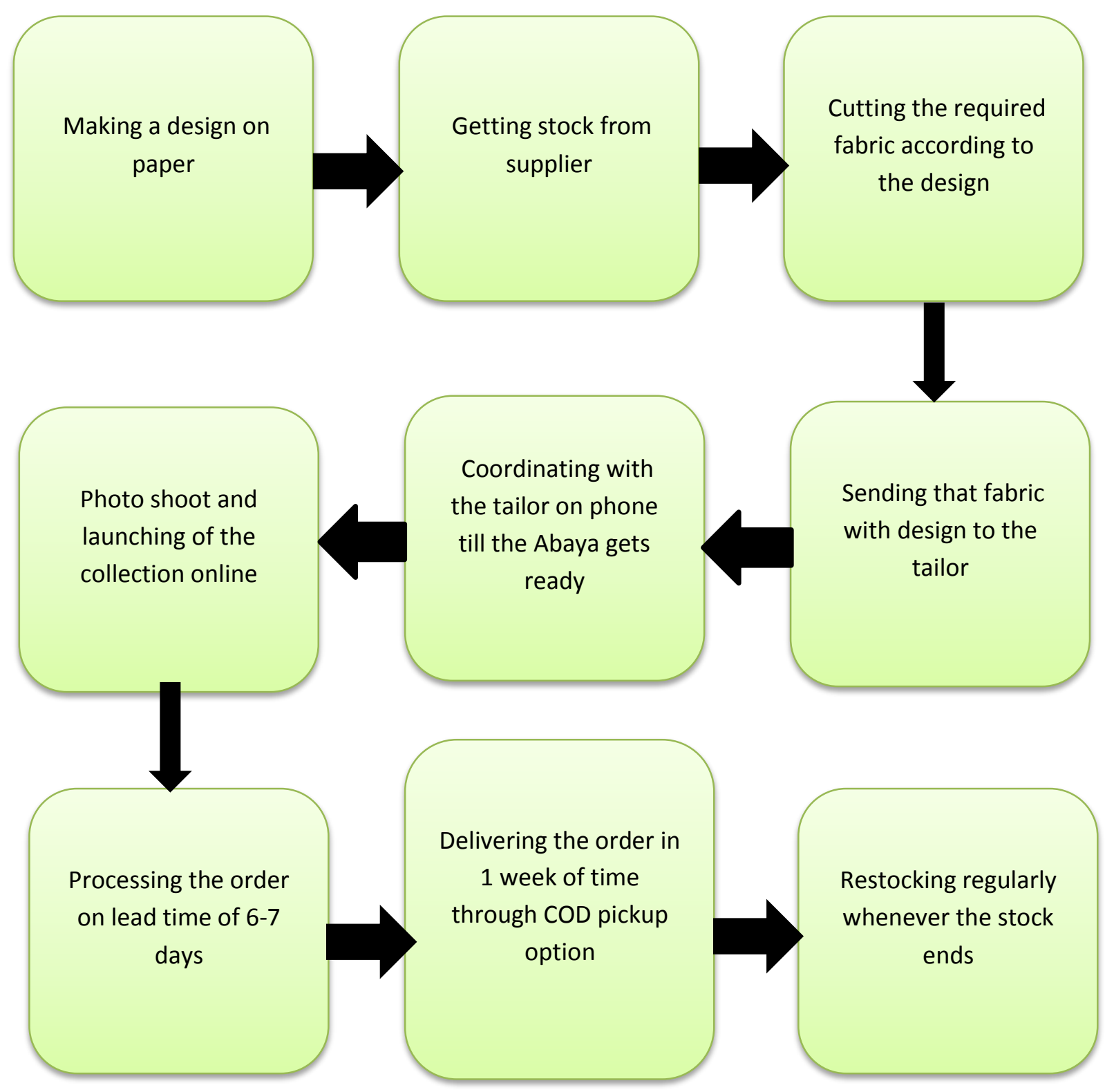




\section{Exhibit 4: Reviews at ABAA's Face Book Page}

Mia El'moro reviewed ABAA - 6*

February 26 at 9:38am - 0

My experiance with Abaa was great Alhamdulillah. I think cape ameerah and waterfall is a must have for every girl who covers
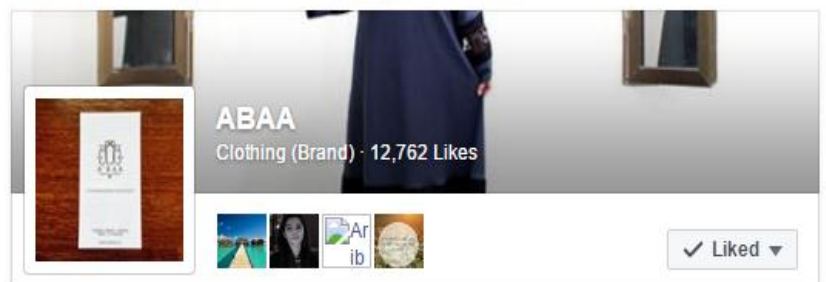

In Like Comment $\Rightarrow$ Share

( 1

(2) ABAA JzkAllah 0

Just got my cape wrap today $n$ its absolutely brilliant! Love the fabric $n$ the color too!...thnku so much...

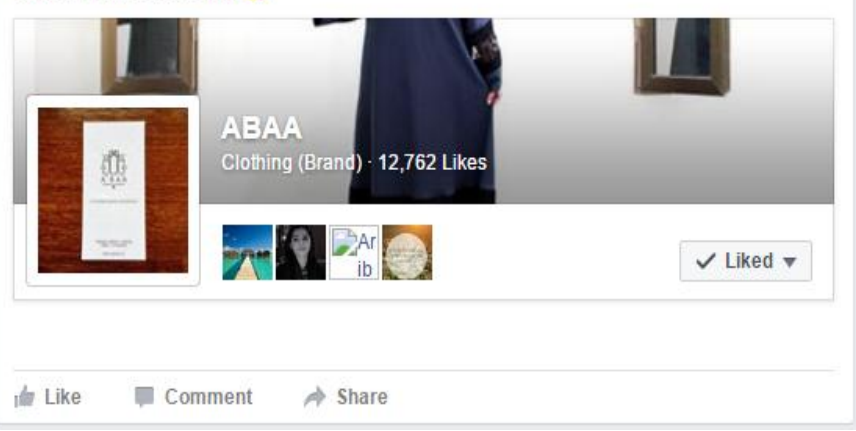

Daf Meena Mustafa Osama reviewed ABAA - 6* October 6,2016-a

I have shopped time and again from Abaa and I have never been disappointed $\because$ Just received my third abaya and the stitching, fabric etc everything is perfect. Keep up the good work Hareem. And the plus point is the owner is really sweet, you'll always get an answer from her and she'll reply to every query in the best possible manner. $:$
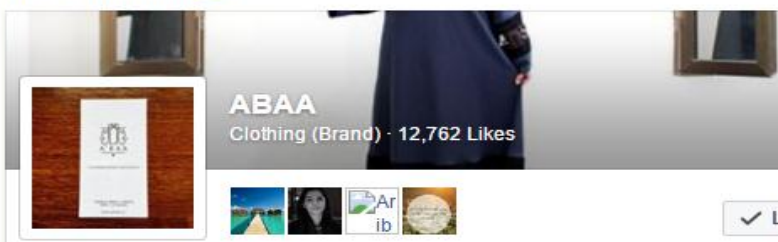

\section{I血 Like \\ (1) Comment \\ $\Rightarrow$ Share}

(6)

C ABAA Jazak Allah Khair for your genuine feels Zarmina. We love it when you trust us! Like - Reply - October 6, 2016 at 8:26am 
Exhibit 5: Products at ABAA
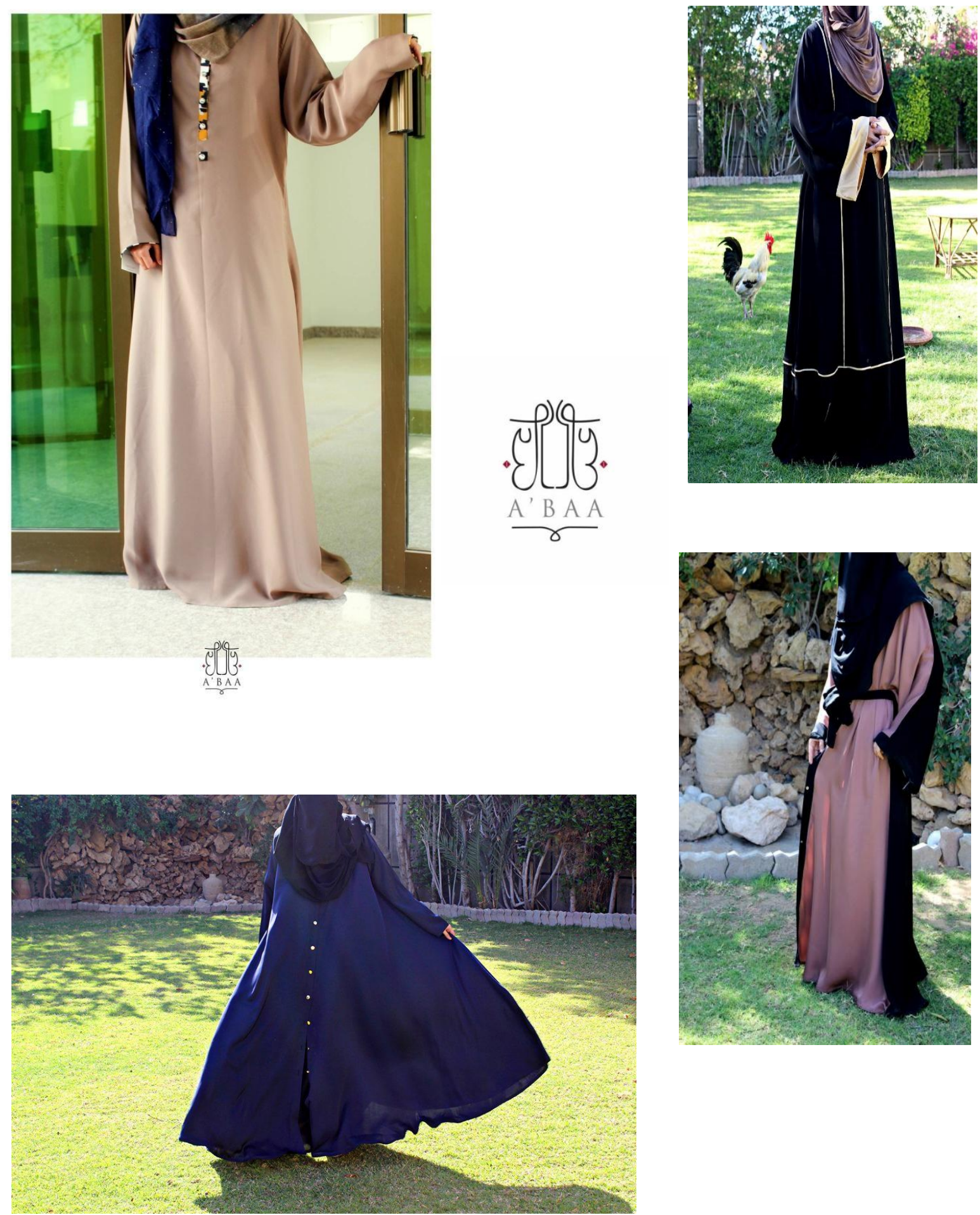

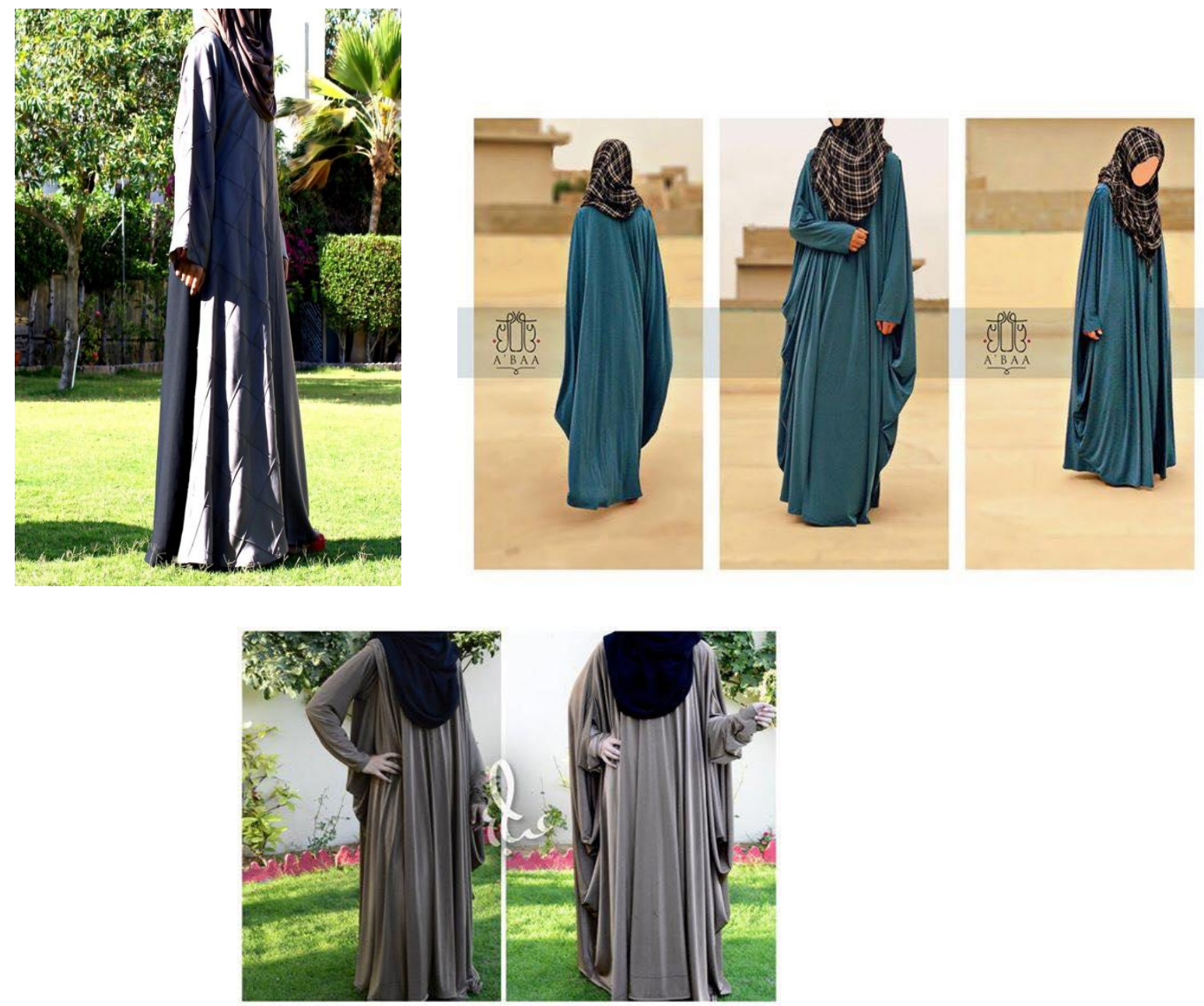

Exhibit 6: 2016 Monthly Sales 
February 2016

Number of Deliveries $\quad 49$

Sales

161,590

Total Cost Incurred

97,800

Profit

$\underline{63,790}$

Percentage Profit

$65.22 \%$

March 2016

Number of Deliveries $\quad 63$

Sales

223,500

Total Cost Incurred

120,000

Profit

$\underline{103,500}$

Percentage Profit

$86.25 \%$

April 2016

Number of Deliveries

52

Sales

161,660

Total Cost Incurred

106,550

Profit

$\underline{55,110}$

Percentage Profit

$51.72 \%$ 
May 2016

Number of Deliveries

Sales

Average Cost Incurred

Profit

Percentage Profit

*June was off due to the month of Ramadan

July 2016

Number of Deliveries

Sales

Total Cost Incurred

Profit

Percentage Profit
50

180,000

112,000

$\underline{68,000}$

$60.71 \%$
40

133,580

83,100

$\underline{50,480}$

$60.75 \%$ 